\title{
Convenient synthesis of polybrominated imidazole building blocks
}

\author{
Constantinos Neochoritis, Constantinos A. Tsoleridis, * and Julia Stephanidou-Stephanatou \\ Department of Chemistry, Laboratory of Organic Chemistry, University of Thessaloniki, 54124, \\ Macedonia, Greece \\ E-mail: tsolerid@chem.auth.gr
}

\begin{abstract}
The synthesis of the hitherto unknown 1-phenylamino-4,5-dimethylimidazole derivatives $\mathbf{3}, \mathbf{4}$ and $\mathbf{5}$ is shown and a bromination study is described by using $N$-bromosuccinimide. It is extremely remarkable that under mild but nevertheless free radical reaction conditions, even by using drastically increasing amounts of NBS (up to 8 eq.) the bromination provides regioselectively in very good yields only the corresponding 2-bromoimidazoles, whereas no side chain bromination to the 4- and 5-methyl groups is observed. However, under more drastic reaction conditions, reflux in $\mathrm{CCl}_{4}$, polybromination takes place and polybrominated imidazole building blocks are formed in good yields.
\end{abstract}

Keywords: Acetylation, bromination, $N$-bromosuccinimide, imidazoles, regioselectivity

\section{Introduction}

Heterocyclic compounds are rich sources of diverse physical, chemical, and biological properties. ${ }^{1}$ In medicinal chemistry they are commonly used as templates to design biologically active agents. ${ }^{2}$ Imidazole-based heterocyclic molecules play important roles in various biochemical processes. ${ }^{3}$ Therefore, the imidazolyl moiety is being used as a building block in developing new drugs. ${ }^{3 \mathrm{~b}, 4}$ Moreover, imidazole derivatives have wide range applications in coordination chemistry, ${ }^{5}$ organometallic catalysis, ${ }^{6}$ and asymmetric catalysis. ${ }^{7}$ There are several reports for the synthesis and functionalization of the imidazole moiety. ${ }^{8}$ The most efficient synthetic routes to polyfunctional compounds involve halogen-metal exchange on iodo- or bromoimidazoles. ${ }^{9}$ In addition, bromination of aromatic and heteroaromatic compounds is an important reaction in synthetic organic chemistry. ${ }^{10}$ On the other hand, brominated and polybrominated arenes and heteroarenes are useful as pharmaceuticals, agrochemicals, flame retardants and specialty chemicals. ${ }^{11}$ Consequently, the bromination of the imidazole ring is of high synthetic interest and efforts have to be made to develop this reaction. Singh and coworkers $^{12}$ have disclosed the monobromination of alkyl activated nitroimidazoles using the 
$\mathrm{DMF}-\mathrm{Br}_{2}$ complex and very recently, the same complex was used for large scale preparation of polybrominated imidazoles. ${ }^{13}$ In addition, some highly substituted imidazolones were converted to 2-bromoimidazoles by reflux with phosphorus oxychloride in toluene for $6 \mathrm{~h}^{14}$ The exhaustive bromination of a variety of benzimidazoles with bromine ${ }^{15}$ and of some tetrahydrobenzimidazoles with NBS at $-10{ }^{\circ} \mathrm{C}$ has also been studied recently. ${ }^{16}$ The need for an easy access to brominated imidazoles aiming at the functionalization of the imidazole ring as well as of the methyl groups of substituted imidazoles led us to the synthesis of 4,5-dimethyl substituted imidazole derivatives and to the study of their nuclear versus side chain bromination. It should also be noticed that only in a few cases, the rates of nuclear versus side chain bromination have been compared within the same substrate, especially when heterocyclic rings are concerned. ${ }^{17}$ Moreover, whereas nuclear bromination has been observed under apparent radical conditions, side chain bromination has not been reported as a side reaction of electrophilic substitution.

\section{Results and Discussion}

Our synthetic approach is depicted in Scheme 1. 4,5-Dimethyl-1-(phenylamino)-1H-imidazole$2(3 H)$-thione (1) was prepared according to a known procedure ${ }^{18,4 b}$ by the reaction of 3-chloro-2butanone with potassium thiocyanate and phenylhydrazine. However, a careful study of its NMR spectrum revealed that in $\mathrm{CDCl}_{3}$ solution compound $\mathbf{1}$ tautomerizes between forms $\mathbf{1 a}$ and $\mathbf{1 b}$. More specifically, the $\mathrm{NH}$ ring proton of $\mathbf{1 a}$ resonates at $\delta 11.25$, whereas the SH proton of $\mathbf{1 b}$ resonates at $\delta 4.78$, their ratio being 2:1. Compound 1 was desulfurized ${ }^{19}$ to the imidazole 2 with $\mathrm{H}_{2} \mathrm{O}_{2}$. Methylation of the phenylamino substituent proceeded smoothly with sodium hydride and methyl iodide in THF and the $N$-methylanilinoimidazole 3 was isolated in $65 \%$ yield.

On the contrary, when acetylation of the phenylamino substituent was attempted by the use of acetyl chloride in the presence of triethylamine, the hitherto unknown very interesting acetylated $\mathrm{N}$-oxide $\mathbf{4}$ was isolated in $59 \%$ yield (Scheme 1). The same $\mathrm{N}$-oxide $\mathbf{4}$ was isolated in $61 \%$ yield, when dimethylaminopyridine (DMAP) was used in addition to triethylamine, whereas by using acetyl chloride in the presence of pyridine the expected acetylated product 5 was isolated in $65 \%$ yield. Finally, by using acetic anhydride in chloroform a mixture of compounds $\mathbf{4}$ and $\mathbf{5}$ was formed in $29 \%$ and $30 \%$ yield, respectively.

The formation of compound $\mathbf{4}$ can be explained by assuming a nucleophilic attack of water at 2-position during purification of $\mathbf{5}$ on column chromatography.

To investigate the bromination of the $N$-methyl- and $N$-acetyl- anilinoimidazoles $\mathbf{3}$ and $\mathbf{5}$, we have proceeded systematically and comparatively using different brominating reagents and conditions. Thus, the $N$-methylanilinoimidazole derivative 3 was treated with NBS in carbon tetrachloride solution over a 200W light bulb and the results are presented in Scheme 2 and in Table 1. By using 1.2-6.0 equivalents of NBS at r.t. after $12 \mathrm{~h}$ only the 2-bromoimidazole 6 was isolated in $88-93 \%$ yield (Table 1: entries 1 and 2). When the same reaction was repeated under 
reflux after a short reaction time, namely $5 \mathrm{~min}$, a mixture of the 2-bromoimidazole 6 and of the 4'-bromophenyl-2-bromoimidazole derivative 7 was formed, compound 6 being completely transformed to 7 during the next 15 min after addition of 1 eq. more NBS (78\% yield) (Table 1: entries 3 and 4). These results can be rationalized by accepting that electrophilic nucleous bromination overrides methyl bromination even under free radical conditions.

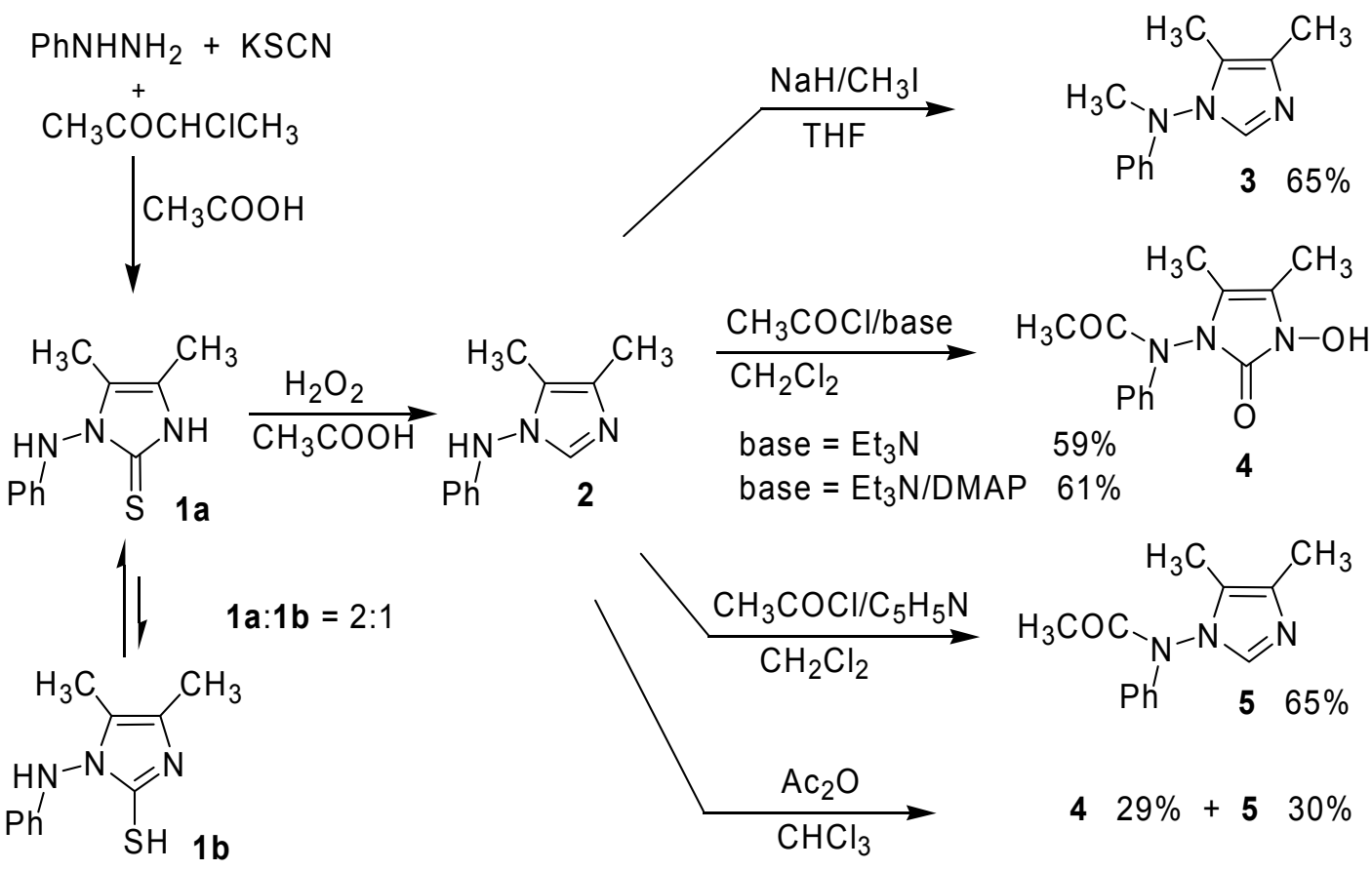

\section{Scheme 1}

By increasing the amount of NBS (2.5 up to 5 eq.), bromination of the methyl groups also takes place and mixtures of polybrominated compounds are formed $(\mathbf{7}, \mathbf{8 , 9}$ ) (Table 1: entry 5). However, by using 6 eq. of NBS mainly the tribromo derivative $\mathbf{8}$ was formed after 20 min, which was completely converted to the tetrabromo derivative 9 after $1 \mathrm{~h}$ (65\% yield) (Table 1: entries 6 and 7) proving thus, that for the free radical bromination of the methyl groups a combination of light/temperature is required. The same tetrabromo derivative 9 was formed (57\% yield) by using benzoylperoxide as radical initiator (Table 1: entry 8). Next, 2,2'azobisisobutyronitrile (AIBN) was used whereupon, when $N$-methylanilinoimidazole 3 was treated with 1.2 eq. of NBS in carbon tetrachloride, at ambient temperature, the dibromo derivative 7 was regioselectively formed in $42 \%$ yield. The same regioselectivity was observed even by increasing the amount of NBS to 8 eq. in the presence of AIBN, whereupon 7 was again formed as the only product at ambient temperature (74\% yield) (Table 1: entries 9 and 10). However, when the reaction was repeated under drastically free radical conditions, namely under reflux in the presence of AIBN with 2.5 up to 5.0 eq. of NBS, the regioselectivity diminishes and a mixture of compounds 7, 8 and 9 was formed (Table 1: entry 11). Finally, when a blank experiment was performed at room temperature by using 1.2 equivalents of NBS only $\mathbf{6}$ was 
isolated in $91 \%$ yield after $30 \mathrm{~h}$. By increasing the amount of NBS to 8.0 equivalents 6 was again formed along with traces of the dibromo derivative 7 after $5 \mathrm{~h}$ at r.t. (Table 1: entries 12 and 13), indicating thus that the presence of AIBN speeds up the formation of 7.

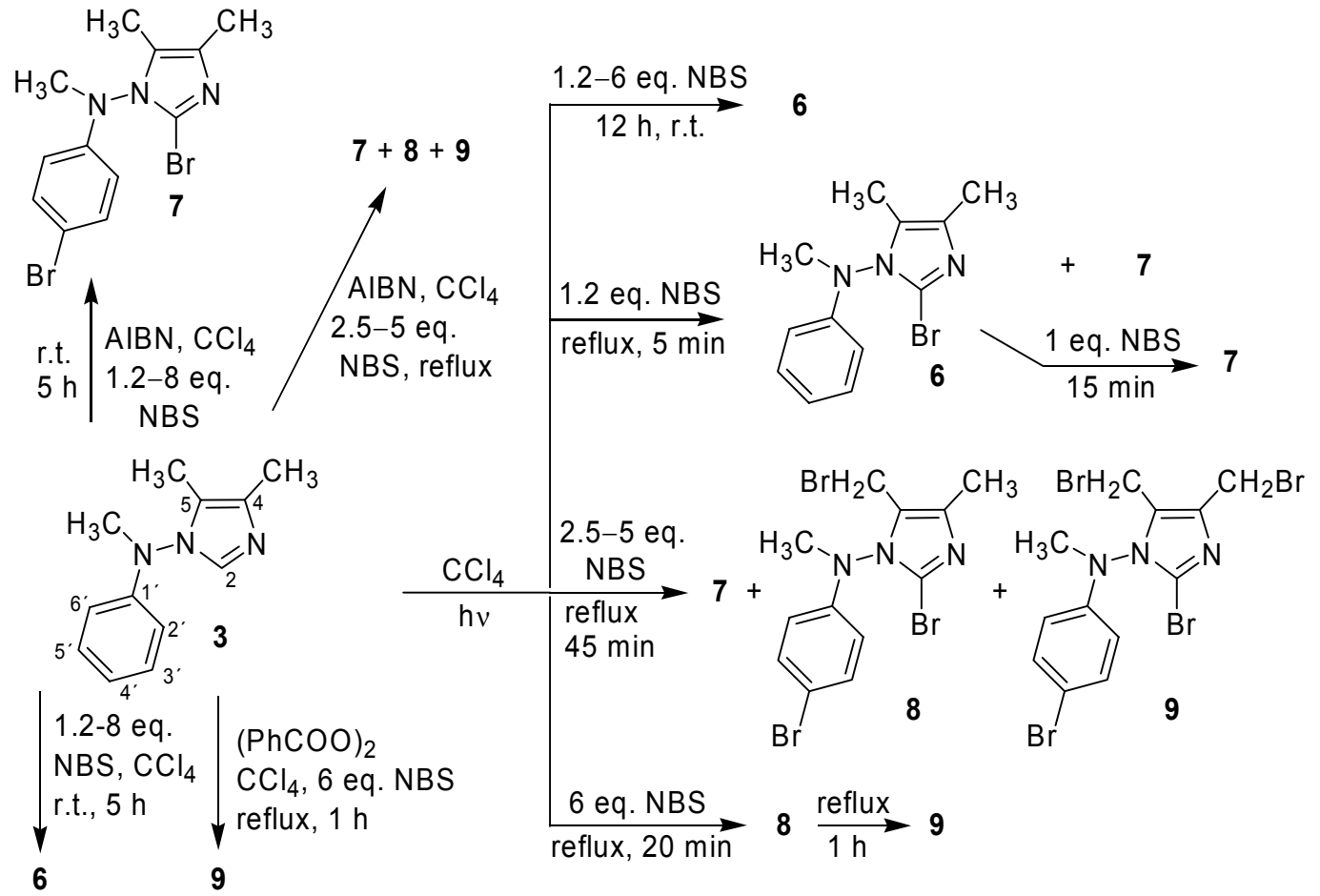

\section{Scheme 2}

Table 1. Various conditions and products during the bromination of 3 in $\mathrm{CCl}_{4}$ by NBS

\begin{tabular}{lccccc}
\hline Entry & $\begin{array}{c}\text { Radical } \\
\text { initiator }\end{array}$ & $\begin{array}{c}\text { NBS } \\
\text { equiv. }\end{array}$ & $\begin{array}{c}\text { Time } \\
(\mathrm{min})^{\mathrm{a}}\end{array}$ & $\begin{array}{c}\text { Tempera- } \\
\text { ture }\end{array}$ & $\begin{array}{c}\text { Product } \\
(\%)\end{array}$ \\
\hline 1 & $\mathrm{~h} v$ & 1.2 & $12 \mathrm{~h}$ & r.t. & $\mathbf{6}(88)$ \\
2 & $\mathrm{~h} v$ & 6.0 & $12 \mathrm{~h}$ & r.t. & $\mathbf{6}(93)$ \\
3 & $\mathrm{~h} v$ & 1.2 & 5 & reflux & $\mathbf{6 + 7}^{\mathrm{b}}$ \\
4 & $\mathrm{~h} v$ & 2.2 & 20 & reflux & $\mathbf{7}(78)$ \\
5 & $\mathrm{~h} v$ & $2.5-5.0$ & 45 & reflux & $\mathbf{7 + \mathbf { 8 } ^ { + } + 9 ^ { \mathrm { b } }}$ \\
6 & $\mathrm{~h} v$ & 6.0 & 20 & reflux & $\mathbf{8}^{+} \mathbf{9}^{\mathrm{b}}$ \\
7 & $\mathrm{~h} v$ & 6.0 & 60 & reflux & $\mathbf{9}(65)$ \\
8 & $(\mathrm{PhCOO})_{2}$ & 6.0 & 60 & reflux & $\mathbf{9}(57)$ \\
9 & $\mathrm{AIBN}$ & 1.2 & $24 \mathrm{~h}$ & r.t. & $\mathbf{7}(42)$ \\
10 & $\mathrm{AIBN}$ & 8.0 & $5 \mathrm{~h}$ & r.t. & $\mathbf{7}(74)$ \\
11 & AIBN & $2.5-5.0$ & 45 & reflux & $\mathbf{7 + 8}+\mathbf{9}^{\mathrm{b}}$ \\
12 & none & 1.2 & $30 \mathrm{~h}$ & r.t. & $\mathbf{6}(91)$ \\
13 & none & 8.0 & $5 \mathrm{~h}$ & r.t. & $\mathbf{6 + 7 ( \text { trace } )}$ \\
\hline
\end{tabular}

${ }^{\mathrm{a}}$ Or in $\mathrm{h}$, as indicated. ${ }^{\mathrm{b}}$ Identified by ${ }^{1} \mathrm{H}$ NMR of the crude mixture. 


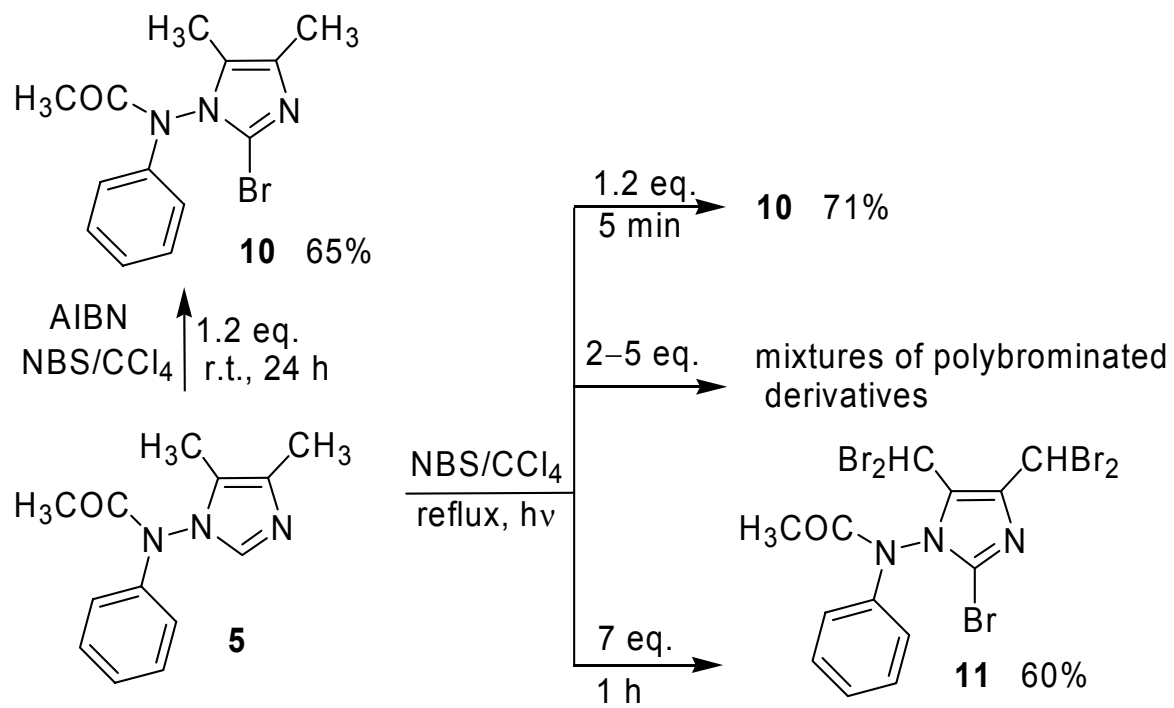

\section{Scheme 3}

Next, $N$-acetylanilinoimidazole 5 was treated with NBS under reflux in carbon tetrachloride solution over a $200 \mathrm{~W}$ light bulb and the results are presented in Scheme 3. By using only 1.2 eq. of NBS after a short reaction time, namely $5 \mathrm{~min}$, only 2-bromoimidazole $\mathbf{1 0}$ was formed in 71\% yield. By increasing the amount of NBS, bromination of the methyl groups also takes place and mixtures of polybrominated compounds are formed. However, by using 7 eq. of NBS only the pentabromo derivative 11 was formed after $1 \mathrm{~h}$ (60\% yield). Finally, the 2-bromoimidazole derivative 10 was again isolated in $65 \%$ yield by using AIBN and 1.2 eq. of NBS at ambient temperature. It should also be mentioned that the N-substituent on the phenylamino group controls the bromination on the phenyl ring. Thus, in the case of an activating methyl group, phenyl bromination is also observed, whereas in the presence of an electron withdrawing group the phenyl ring is deactivated.

Since there is little methodology available for regioselective functionalization of imidazoles at the C-2 position, ${ }^{20}$ we feel that this method for the regioselective bromination of imidazoles may find application in the synthesis of imidazole containing natural products. ${ }^{21}$

All products were unequivocally characterized by MS and NMR spectra $\left({ }^{1} \mathrm{H},{ }^{13} \mathrm{C}, \mathrm{H}-\mathrm{H}\right.$ COSY, C-H COSY and C-H COLOC). The assignment of signals corresponding to $\mathrm{C}(4), \mathrm{C}(5)$ as well as to $\mathrm{CH}_{3}-4$ and $\mathrm{CH}_{3}-5$ is supported by the NOESY cross signals between the 5-methyl protons with the aromatic ones as well by the fact that carbons in position 5 have sterically induced upfield shifts.

Regarding the structure of compound 4, its molecular formula is supported from the elemental analysis and mass spectra. The presence of an acetyl moiety introduced to the phenylamino group was unequivocally established from the NMR spectra (see experimental) and also from the carbonyl absorption in the IR spectrum at $1666 \mathrm{~cm}^{-1}$. Concerning the hydroxyl group it appears in the ${ }^{1} \mathrm{H}$ NMR as a broad singlet at $\delta 12.38$, forming most probably a hydrogen 
bond with the adjacent carbonyl oxygen. This carbonyl carbon resonates at $161.3 \mathrm{ppm}$, whereas the corresponding carbon of starting material 2 resonates at 135.4.

Concerning the structure of compound $\mathbf{8}$, the position of the third bromine was unequivocally established from the ${ }^{1} \mathrm{H}$ NMR of the $5-\mathrm{CH}_{2} \mathrm{Br}$ group which appears as an AB system (doublet of doublets) at $\delta 4.26$ and 4.43 with $J=11.5 \mathrm{~Hz}$, due to restricted rotation being in the vicinity of the N-1 substituent. Analogous behaviour is observed in the case of compound 9, where the 5$\mathrm{CH}_{2} \mathrm{Br}$ group appears as an $\mathrm{AB}$ system with $J=12.2 \mathrm{~Hz}$, whereas the 4- $\mathrm{CH}_{2} \mathrm{Br}$ group, suffering no restricted rotation appears as a singlet.

By the identification of compound $\mathbf{8}$ the bromination sequence of $\mathbf{3}$ was unequivocally established as follows: Initial bromination occurs at position $\mathrm{C}-2$ and is followed by the bromination at position $\mathrm{C}-4^{\prime}$. Subsequent bromination takes place at the more crowded $5-\mathrm{CH}_{3}$ group and finally the $4-\mathrm{CH}_{3}$ is brominated.

In summary, the synthesis of the hitherto unknown 1-phenylamino-4,5-dimethylimidazole derivatives 3, 4 and $\mathbf{5}$ is described and a bromination study leading to the regioselective functionalization of imidazoles at the $\mathrm{C}-2$ position, which may find application in the synthesis of imidazole containing natural products, is presented. Furthermore, it is established that the $N$ substituent on the phenylamino group controls the bromination on the N-phenyl ring. Under more drastic reaction conditions polybromination takes place and polybrominated imidazole building blocks are formed in good yields. For all new compounds full assignment of proton and carbon NMR chemical shifts was achieved. The reactivity of the polybromoimidazole scaffolds is now under investigation.

\section{Experimental Section}

General Procedures. Melting points were measured on a Kofler hot-stage and are uncorrected. Column chromatography was carried out using Merck silica gel (70-230 mesh). Petroleum ether refers to the fraction boiling between 60 and $80{ }^{\circ} \mathrm{C}$. NMR spectra were recorded on a Bruker AM 300 spectrometer at $300 \mathrm{MHz}$ for ${ }^{1} \mathrm{H}$ and $75 \mathrm{MHz}$ for ${ }^{13} \mathrm{C}$, respectively, using $\mathrm{CDCl}_{3}$ as solvent. The chemical shifts are expressed in $\delta$ values (ppm) relative to TMS as internal standard for ${ }^{1} \mathrm{H}$ and relative to TMS $(0.00 \mathrm{ppm})$ or to $\mathrm{CDCl}_{3}(77.05 \mathrm{ppm})$ for ${ }^{13} \mathrm{C} \mathrm{NMR}$ spectra. Coupling constants ${ }^{n} J$ are reported in Hz. Low resolution electron impact mass spectra (EIMS) were obtained on a VG TS-250 instrument and elemental analyses performed with a Perkin-Elmer 2400-II CHN analyzer.

\section{2,3-Dihydro-4,5-dimethyl-1-phenylamino-1 $H$-imidazole-2-thione (1)}

The compound was synthesized in $70 \%$ yield according to a known procedure. ${ }^{18} \mathrm{Mp} 229-231{ }^{\circ} \mathrm{C}$ (lit. $\left.{ }^{18} 230-232{ }^{\circ} \mathrm{C}\right) .{ }^{1} \mathrm{H}$ NMR $\delta$ ppm: 2.04 (s, 3H, 5- $\mathrm{CH}_{3}$ ), 2.09 (s, 3H, 4-CH $), 4.78$ (br s, 0.333H, $\mathrm{SH}), 6.66$ (d, $\left.J=8.4 \mathrm{~Hz}, 2 \mathrm{H}, 2^{\prime}, 6^{\prime}\right), 6.96$ (t, $J=7.4 \mathrm{~Hz}, 1 \mathrm{H}, 4^{\prime}$ ), 7.11 (br s, 1H, PhNH), 7.25 (dd, $\left.J_{l}=8.4, J_{2}=7.4 \mathrm{~Hz}, 2 \mathrm{H}, 3^{\prime}, 5^{\prime}\right), 11.25$ (br s, 0.667H, NH). ${ }^{13} \mathrm{C}$ NMR $\delta$ ppm: $7.2\left(5-\mathrm{CH}_{3}\right), 8.5$ (4- 
$\left.\mathrm{CH}_{3}\right), 112.5$ (2',6'), 117.1 (5), 120.0 (4'), 121.9 (4), 128.2 (3',5'), 145.9 (1'), 158.3 (2). EIMS: $\mathrm{m} / \mathrm{z}(\%) 219\left(\mathrm{M}^{+}, 100\right), 203$ (50), 186 (70), 177 (25), 161 (15), 151 (65), 136 (28), 128 (30), 93 (30).

4,5-Dimethyl-1-phenylamino- $1 \mathrm{H}$-imidazole (2). The compound was synthesized in $80 \%$ yield according to a known procedure. ${ }^{19} \mathrm{Mp} 178-180{ }^{\circ} \mathrm{C}$ (lit. ${ }^{19} 175-177{ }^{\circ} \mathrm{C}$ ). ${ }^{1} \mathrm{H}$ NMR $\delta$ ppm: 2.00 (s, $\left.3 \mathrm{H}, 5-\mathrm{CH}_{3}\right), 2.19\left(\mathrm{~s}, 3 \mathrm{H}, 4-\mathrm{CH}_{3}\right), 6.51\left(\mathrm{~d}, J=8.0 \mathrm{~Hz}, 2 \mathrm{H}, 2^{\prime}, 6^{\prime}\right), 6.90$ (t, $\left.J=7.3 \mathrm{~Hz}, 1 \mathrm{H}, 4^{\prime}\right), 7.22$ $\left(\mathrm{dd}, J_{1}=8.0, J_{2}=7.3 \mathrm{~Hz}, 2 \mathrm{H}, 3^{\prime}, 5^{\prime}\right), 7.44(\mathrm{~s}, 1 \mathrm{H}, \mathrm{NH}), 7.55(\mathrm{~s}, 1 \mathrm{H}, 2) .{ }^{13} \mathrm{C} \mathrm{NMR} \delta$ ppm: $7.5(5-$ $\mathrm{CH}_{3}$ ), $13.1\left(4-\mathrm{CH}_{3}\right), 121.1\left(4^{\prime}\right), 112.5$ (2',6'), 123.5 (5), 129.4 (3',5'), 132.2 (4), 135.4 (2), 147.2 (1'). EIMS: $m / z(\%) 187\left(\mathrm{M}^{+*}, 99\right), 145$ (83), 131 (20), 104 (90), 92 (100).

\section{$\mathrm{N}, 4,5$-trimethyl- $N$-phenyl-1 $H$-imidazole-1-amine (3)}

To a suspension of compound $2(0.094 \mathrm{~g}, 0.5 \mathrm{mmol})$ in dry tetrahydrofuran $(20 \mathrm{~mL})$ at $0{ }^{\circ} \mathrm{C}$ sodium hydride $(0.04 \mathrm{~g}$ of $60 \%$ in oil, $1.1 \mathrm{mmol})$ was added. Salt formation was allowed to proceed at ambient temperature for $30 \mathrm{~min}$, methyliodide $(0.15 \mathrm{~g}, 1.0 \mathrm{mmol})$ was then added and the solution was stirred for $1.5 \mathrm{~h}$. Water was added, the organic layer was washed with water, dried $\left(\mathrm{Na}_{2} \mathrm{SO}_{4}\right)$ and concentrated. The methylated product was crystallized by the addition of petroleum ether as a yellow solid, $0.065 \mathrm{~g}, 65 \%$ yield. $\mathrm{Mp} 78-80{ }^{\circ} \mathrm{C}\left(\mathrm{CH}_{2} \mathrm{Cl}_{2}\right.$-petroleum ether). ${ }^{1} \mathrm{H}$ NMR $\delta$ ppm: 1.97 (s, 3H, 5- $\left.\mathrm{CH}_{3}\right), 2.21\left(\mathrm{~s}, 3 \mathrm{H}, 4-\mathrm{CH}_{3}\right), 3.38\left(\mathrm{~s}, 3 \mathrm{H}, N-\mathrm{CH}_{3}\right), 6.47(\mathrm{~d}, J=8.0$ $\left.\mathrm{Hz}, 2 \mathrm{H}, 2^{\prime}, 6^{\prime}\right), 6.91\left(\mathrm{t}, J=7.5 \mathrm{~Hz}, 1 \mathrm{H}, 4^{\prime}\right), 7.25\left(\mathrm{dd}, J_{1}=8.0, J_{2}=7.5 \mathrm{~Hz}, 2 \mathrm{H}, 3^{\prime}, 5^{\prime}\right), 7.50(\mathrm{~s}, 1 \mathrm{H}$, 2). ${ }^{13} \mathrm{C}$ NMR $\delta$ ppm: $7.9\left(5-\mathrm{CH}_{3}\right), 13.1\left(4-\mathrm{CH}_{3}\right), 41.5\left(N-\mathrm{CH}_{3}\right), 112.5\left(2^{\prime}, 6^{\prime}\right), 120.3\left(4^{\prime}\right), 123.5$ (5), 129.3 (3',5'), 133.8 (2), 133.9 (4), 148.9 (1'). EIMS: m/z (\%) $201\left(\mathrm{M}^{+*}, 82\right), 186$ (5), 159 (21), 118 (30), 106 (100). Anal. Calcd for $\mathrm{C}_{12} \mathrm{H}_{15} \mathrm{~N}_{3}$ (201.27): C, 71.61; H, 7.51; N, 20.88 .

Reaction of 2 with $\mathrm{CH}_{3} \mathrm{COCl} / \mathrm{Et}_{3} \mathrm{~N}$. Formation of 1-(acetylphenylamino)-1,3-dihydro-3hydroxy-4,5-dimethyl-2H-imidazol-2-one (4)

Acetylchloride $(0.10 \mathrm{~g}, 1.3 \mathrm{mmol})$ was added dropwise to a solution of $2(0.094 \mathrm{~g}, 0.5 \mathrm{mmol})$ and dry triethylamine $(0.060 \mathrm{~g}, 0.59 \mathrm{mmol})$ in anhydrous methylene chloride $(3 \mathrm{~mL})$. The reaction mixture was stirred at room temperature for $48 \mathrm{~h}$, and then poured into water. The organic layer was washed with $5 \% \mathrm{NaHCO}_{3}$ solution, with $5 \% \mathrm{HCl}$ solution, finally with water, and then was dried over $\mathrm{Na}_{2} \mathrm{SO}_{4}$. The solvent was then removed and the residue was purified on a silica gel column using petroleum ether-EtOAc (1:1) as eluent, whereupon compound 4 was isolated as white crystals, $0.078 \mathrm{~g}, 59 \%, \mathrm{mp} 205-207{ }^{\circ} \mathrm{C}$ (ethanol). ${ }^{1} \mathrm{H}$ NMR $\delta$ ppm: 2.01 (s, 3H, 5- $\left.\mathrm{CH}_{3}\right), 2.11\left(\mathrm{~s}, 3 \mathrm{H}, 4-\mathrm{CH}_{3}\right), 2.16\left(\mathrm{~s}, 3 \mathrm{H}, \mathrm{COCH}_{3}\right), 7.23\left(\mathrm{~m}, 1 \mathrm{H}, 4^{\prime}\right), 7.36\left(\mathrm{~m}, 2 \mathrm{H}, 3^{\prime}, 5^{\prime}\right), 7.55(\mathrm{~d}$, $\left.J=9.0 \mathrm{~Hz}, 2 \mathrm{H}, 2^{\prime}, 6^{\prime}\right), 12.38$ (br s, $\left.1 \mathrm{H}, \mathrm{OH}\right) .{ }^{13} \mathrm{C} \mathrm{NMR} \delta \mathrm{ppm}: 8.4$ (br, 5- $\left.\mathrm{CH}_{3}\right), 9.3\left(4-\mathrm{CH}_{3}\right), 25.6$ (br, $\mathrm{COCH}_{3}$ ), 119.9 (5), 121.3 (4), 123.2 (2',6'), 126.8 (4'), 128.9 (3',5'), 139.5 (1'), 161.3 (2), $170.8(\mathrm{C}=\mathrm{O})$. EIMS: $m / z(\%) 261\left(\mathrm{M}^{+}, 55\right), 246$ (48), 203 (20), 125 (100). Anal. Calcd for $\mathrm{C}_{13} \mathrm{H}_{15} \mathrm{~N}_{3} \mathrm{O}_{3}$ (261.28): C, 59.76; H, 5.79; N, 16.08. Found: C, 59.59; H, 5.67; N, 16.13.

\section{Reaction of compound 2 with $\mathrm{CH}_{3} \mathrm{COCl} / \mathrm{Et}_{3} \mathrm{~N} / \mathrm{DMAP}$. -Formation of compound 4}

Acetylchloride $(0.270 \mathrm{~g}, 3.4 \mathrm{mmol})$ was added dropwise to a solution of $2(0.187 \mathrm{~g}, 1.0 \mathrm{mmol})$, dry triethylamine $(0.05 \mathrm{~g}, 0.50 \mathrm{mmol})$ and dimethylaminopyridine (DMAP) $(0.06 \mathrm{~g}, 0.4 \mathrm{mmol})$ in anhydrous methylene chloride $(3 \mathrm{~mL})$. The reaction mixture was stirred at room temperature for $48 \mathrm{~h}$, and then worked up as above to give compound 4, $0.159 \mathrm{~g}, 61 \%$ yield. 


\section{Reaction of compound 2 with $\mathrm{CH}_{3} \mathrm{COCl} /$ pyridine.- Formation of 4,5-dimethyl- $N$ - phenylacetylamido-1 $H$-imidazole (5)}

To an ice cooled solution of $2(0.374 \mathrm{~g}, 2.0 \mathrm{mmol})$ in anhydrous methylene chloride $(3 \mathrm{~mL})$ dry pyridine $(0.158 \mathrm{~g}, 2.0 \mathrm{mmol})$ was added followed by the dropwise addition of acetylchloride $(0.5$ $\mathrm{g}, 2.6 \mathrm{mmol})$. The reaction mixture was stirred at room temperature for $48 \mathrm{~h}$, and then poured into water. The organic layer was washed with $5 \% \mathrm{NaHCO}_{3}$ solution, with $5 \% \mathrm{HCl}$ solution, finally with water, and then was dried over $\mathrm{Na}_{2} \mathrm{SO}_{4}$. The solvent was then evaporated under reduced pressure. The residue was crystallized, by addition of methylene chloride and ether, to give white crystals of compound 5 in $65 \%$ yield. $\mathrm{Mp} 118-120^{\circ} \mathrm{C}$ (methylene chloride-ether). IR $\left(\mathrm{cm}^{-1}\right): 1694(\mathrm{C}=\mathrm{O}) .{ }^{1} \mathrm{H}$ NMR $\delta$ ppm: 2.02 (s, 3H, $\left.\mathrm{COCH}_{3}\right), 2.07$ (s, 3H, 5-CH $), 2.19$ (s, 3H, 4$\left.\mathrm{CH}_{3}\right), 7.20-7.32\left(\mathrm{~m}, 3 \mathrm{H}, 3^{\prime}, 4^{\prime}, 5^{\prime}\right), 7.35-7.45$ (m, 2H, 2',6'), 7.60 (s, 1H, 2). ${ }^{13} \mathrm{C}$ NMR $\delta$ ppm: 7.6 (5- $\left.\mathrm{CH}_{3}\right), 13.0\left(4-\mathrm{CH}_{3}\right), 21.7\left(\mathrm{COCH}_{3}\right), 122.0$ (br, 2',6'), 122.5 (5), 126.9 (br, 2), 129.3 (3',5'), 133.0 (br 4), $134.4\left(4^{\prime}\right), 140.1$ (1'), $170.5(\mathrm{C}=\mathrm{O})$. EIMS: $m / z(\%) 229\left(\mathrm{M}^{+*}, 7\right), 186(54), 172$ (5), 145 (25), 118 (100), 104 (45), 93 (48). Anal. Calcd for $\mathrm{C}_{13} \mathrm{H}_{15} \mathrm{~N}_{3} \mathrm{O}$ (229.28): C, 68.10; H, 6.59; N, 18.33. Found: C, 68.29; H, 6.50; N, 18.13.

However, when the reaction mixture is purified on a silica gel column using petroleum etherEtOAc (1:1) as eluent, compound $\mathbf{5}$ is partially transformed to 4.

\section{Acetylation of 2 with $\left(\mathrm{CH}_{3} \mathrm{CO}\right)_{2} \mathrm{O} / \mathrm{CHCl}_{3}$}

Acetic anhydride $(0.174 \mathrm{~g}, 1.3 \mathrm{mmol})$ was added dropwise at $5{ }^{\circ} \mathrm{C}$ to a solution of $2(0.94 \mathrm{~g}, 0.5$ $\mathrm{mmol})$ in anhydrous chloroform $(10 \mathrm{~mL})$. The reaction mixture was stirred at room temperature for $48 \mathrm{~h}$, and then poured into water. The organic layer was washed with $5 \% \mathrm{NaHCO}_{3}$ solution, with $5 \% \mathrm{HCl}$ solution, finally with water, and then was dried over $\mathrm{Na}_{2} \mathrm{SO}_{4}$. By TLC and ${ }^{1} \mathrm{H}-$ NMR of the crude reaction mixture it was established that an approximately 1:1 mixture of 4 and 5 was formed.

\section{Bromination of 3 with NBS and light}

A magnetically stirred mixture of compound $3(0.201 \mathrm{~g}, 1.0 \mathrm{mmol})$ and NBS $(0.214 \mathrm{~g}, 1.2 \mathrm{mmol})$ in anhydrous $\mathrm{CCl}_{4}(15 \mathrm{~mL})$ was irradiated by a $200 \mathrm{~W}$ light bulb at r.t. for $12 \mathrm{~h}$. The end of the reaction was monitored by TLC because with longer irradiation times decomposition of the reaction products is observed. The succinimide which was formed was removed by filtration. Concentration of the filtrate was followed by purification by column chromatography on silica gel using a mixture of petroleum ether-EtOAc (4:1) as eluent to afford.

2-Bromo- $\boldsymbol{N}$-phenyl- $\boldsymbol{N}$-4,5-trimethyl- $\mathbf{H}$-imidazole-1-amine (6). White solid, $0.28 \mathrm{~g}$; yield 88\%, mp 85-87 ${ }^{\circ} \mathrm{C} .{ }^{1} \mathrm{H}$ NMR $\delta$ ppm: 1.99 (s, 3H, 5- $\left.\mathrm{CH}_{3}\right), 2.17$ (s, 3H, 4- $\left.\mathrm{CH}_{3}\right), 3.39$ (s, 3H, N$\left.\mathrm{CH}_{3}\right), 6.44\left(\mathrm{~d}, J=8.7 \mathrm{~Hz}, 2 \mathrm{H}, 2^{\prime}, 6^{\prime}\right), 6.90\left(\mathrm{t}, J=7.5 \mathrm{~Hz}, 1 \mathrm{H}, 4^{\prime}\right), 7.26\left(\mathrm{~m}, 2 \mathrm{H}, 3^{\prime}, 5^{\prime}\right) .{ }^{13} \mathrm{C} \mathrm{NMR} \delta$ ppm: $8.7\left(5-\mathrm{CH}_{3}\right), 13.3\left(4-\mathrm{CH}_{3}\right), 39.8\left(N-\mathrm{CH}_{3}\right), 111.8\left(2^{\prime}, 6^{\prime}\right), 117.0$ (2), $120.2\left(4^{\prime}\right), 126.3$ (5), $129.4\left(3^{\prime}, 5^{\prime}\right), 133.5$ (4), 147.0 (1'). Anal. Calcd for $\mathrm{C}_{11} \mathrm{H}_{12} \mathrm{BrN}_{3}(266.14): \mathrm{C}, 49.64 ; \mathrm{H}, 4.54 ; \mathrm{N}$, 15.79. Found: C, 49.52; H, 4.64; N, 15.88 .

When the same reaction was repeated under irradiation for $12 \mathrm{~h}$ at r.t. with $6.0 \mathrm{mmol} \mathrm{NBS}$ again only compound 6 was isolated in 93\% yield. When the same reaction was repeated with 1.2 mmol NBS under irradiation and reflux, after 5 min a mixture of compound 6 and of compound 
7 was formed. When the same reaction was repeated with 2.2 mmol NBS under irradiation and reflux, after $20 \mathrm{~min}$ the $\mathbf{2}$-bromo- $\boldsymbol{N}$-(4-bromophenyl)- $\mathbf{N , 4 , 5}$-trimethyl-1 $\boldsymbol{H}$-imidazole-1-amine (7) was formed. Yellow solid, $0.28 \mathrm{~g}$; yield 78\%, mp 101-103 ${ }^{\circ} \mathrm{C} .{ }^{1} \mathrm{H}$ NMR $\delta$ ppm: 2.00 (s, 3H, 5- $\left.\mathrm{CH}_{3}\right), 2.20\left(\mathrm{~s}, 3 \mathrm{H}, 4-\mathrm{CH}_{3}\right), 3.38\left(\mathrm{~s}, 3 \mathrm{H}, N-\mathrm{CH}_{3}\right), 6.32(\mathrm{~d}, J=9.0 \mathrm{~Hz}, 2 \mathrm{H}), 7.35(\mathrm{~d}, J=9.0 \mathrm{~Hz}$, 2H). ${ }^{13} \mathrm{C}$ NMR $\delta$ ppm: $8.4\left(5-\mathrm{CH}_{3}\right), 12.9\left(4-\mathrm{CH}_{3}\right), 40.0\left(\mathrm{~N}-\mathrm{CH}_{3}\right), 112.9\left(4^{\prime}\right), 113.6\left(2^{\prime}, 6^{\prime}\right), 116.8$ (2), 126.3 (5), $132.4\left(3^{\prime}, 5^{\prime}\right), 133.4$ (4), 146.3 (1'). EIMS: $m / z(\%) 357 / 359 / 361\left(\mathrm{M}^{+}, 38\right),{ }^{22}$ 278/280 (8), $237 / 239$ (6), 199 (16), 184/186 (100), 174/176 (32), 155/157 (25), 105 (65). Anal. Calcd for $\mathrm{C}_{12} \mathrm{H}_{13} \mathrm{Br}_{2} \mathrm{~N}_{3}$ (359.06): C, 40.14; H, 3.65; N, 11.70. Found: C, 40.38; H, 3.74; N, 11.88 . When the same reaction was repeated with $6 \mathrm{mmol} \mathrm{NBS}$, under reflux and irradiation for $20 \mathrm{~min}$, the 2-bromo-5-bromomethyl- $\boldsymbol{N}$-(4-bromophenyl)- $\boldsymbol{N}$,4-dimethyl-1 $\boldsymbol{H}$-imidazole-1-amine (8) was mainly formed. ${ }^{1} \mathrm{H}$ NMR $\delta$ ppm: $2.27\left(\mathrm{~s}, 3 \mathrm{H}, 4-\mathrm{CH}_{3}\right), 3.49\left(\mathrm{~s}, 3 \mathrm{H}, N-\mathrm{CH}_{3}\right), 4.26(\mathrm{~d}, J=11.5$ $\mathrm{Hz}, 1 \mathrm{H}, 5-\mathrm{CH}_{2} \mathrm{Br}$ ), 4.43 (d, $\left.J=11.5 \mathrm{~Hz}, 1 \mathrm{H}, 5-\mathrm{CH}_{2} \mathrm{Br}\right), 6.34$ (d, $\left.J=9.0 \mathrm{~Hz}, 2 \mathrm{H}, 2^{\prime}, 6^{\prime}\right), 7.36$ (d, $J$ $=9.0 \mathrm{~Hz}, 2 \mathrm{H}, 3^{\prime}, 5^{\prime}$ ), containing an amount (approximately 10\%) of 2-bromo-4,5bisbromomethyl- $\boldsymbol{N}$-(4-bromophenyl)- $\boldsymbol{N}$-methyl- $\mathbf{H}$-imidazole-1-amine (9). However, after irradiation under reflux for $1 \mathrm{~h}, \mathbf{8}$ was completely transformed to $\mathbf{9}$, which was crystallized by addition of ether. Yellow solid, $0.335 \mathrm{~g}$, yield $65 \%$. ${ }^{1} \mathrm{H}$ NMR $\delta$ ppm: $3.51\left(\mathrm{~s}, 3 \mathrm{H}, \mathrm{N}-\mathrm{CH}_{3}\right), 4.30$ (d, $J=12.2 \mathrm{~Hz}, 1 \mathrm{H}, 5-\mathrm{CH}_{2} \mathrm{Br}$ ), 4.48 (d, $\left.J=12.2 \mathrm{~Hz}, 1 \mathrm{H}, 5-\mathrm{CH}_{2} \mathrm{Br}\right), 4.48$ (s, 2H, 4-CH $\mathrm{CH}_{2} \mathrm{Br}, 6.34$ $\left(\mathrm{d}, J=8.8 \mathrm{~Hz}, 2 \mathrm{H}, 2^{\prime}, 6^{\prime}\right), 7.38\left(\mathrm{~d}, J=8.8 \mathrm{~Hz}, 2 \mathrm{H}, 3^{\prime}, 5^{\prime}\right) .{ }^{13} \mathrm{C} \mathrm{NMR} \delta \mathrm{ppm}: 17.3\left(5-\mathrm{CH}_{2}\right), 23.7$ (4$\left.\mathrm{CH}_{2}\right), 40.4\left(\mathrm{~N}-\mathrm{CH}_{3}\right), 113.7\left(4^{\prime}\right), 114.0\left(2^{\prime}, 6^{\prime}\right), 126.0$ (2), 129.2 (5), 132.5 (3',5'), 136.8 (4), 145.9 (1'). Anal. Calcd for $\mathrm{C}_{12} \mathrm{H}_{11} \mathrm{Br}_{4} \mathrm{~N}_{3}$ (516.85): C, 27.89; H, 2.15; N, 8.13. Found: C, 28.00; H, 2.04; $\mathrm{N}, 8.28$. Due to the instability of compound 9 at higher temperature, it was not possible to measure the mp and ms.

\section{Bromination of compound 3 with NBS and (PhCOO)}

To a magnetically stirred mixture of compound $3(0.201 \mathrm{~g}, 1.0 \mathrm{mmol})$ and NBS (1.068 g, 6.0 $\mathrm{mmol})$ in anhydrous $\mathrm{CCl}_{4}(15 \mathrm{~mL})(\mathrm{PhCOO})_{2}(0.048 \mathrm{~g}, 0.2 \mathrm{mmol})$ was added and the mixture was refluxed for $1 \mathrm{~h}$. The succinimide, which was formed, was removed by filtration. Concentration of the filtrate and purification afforded compound 9, $0.294 \mathrm{~g}, 57 \%$ yield.

\section{Bromination of compound 3 with NBS and AIBN}

To a magnetically stirred mixture of compound $3(0.201 \mathrm{~g}, 1.0 \mathrm{mmol})$ and NBS $(0.214 \mathrm{~g}, 1.2$ mmol) in anhydrous $\mathrm{CCl}_{4}(15 \mathrm{~mL})$ AIBN $(0.043 \mathrm{~g}, 0.2 \mathrm{mmol})$ was added and the mixture was stirred at room temperature for $24 \mathrm{~h}$. The succinimide which was formed was removed by filtration. Concentration of the filtrate and purification by column chromatography on silica gel using a mixture of petroleum ether-EtOAc (4:1) as eluent afforded compound 7, $0.151 \mathrm{~g}, 42 \%$ yield, along with unreacted starting material. Analogous results were obtained, when the reaction was repeated with 8.0 eq. of NBS for $5 \mathrm{~h}$, whereupon compound 7 was again isolated as the only reaction product, $0.266 \mathrm{~g}, 74 \%$ yield. However, when the reaction was repeated under reflux with 1.2-8.0 eq. of NBS mixtures of compounds 7, 8 and 9 were formed.

\section{Bromination of compound 3 with NBS}

A mixture of compound $3(0.201 \mathrm{~g}, 1.0 \mathrm{mmol})$ and $\mathrm{NBS}(0.214 \mathrm{~g}, 1.2 \mathrm{mmol})$ in anhydrous $\mathrm{CCl}_{4}$ $(15 \mathrm{~mL})$ was magnetically stirred for $30 \mathrm{~h}$. The succinimide, which was formed, was removed by 
filtration. Concentration of the filtrate and purification afforded compound 6 in $91 \%$ yield. When the same reaction was repeated with $8.0 \mathrm{mmol}$ NBS for $5 \mathrm{~h}$ compound 6 containing an amount (approximately 5\%) of compound 7 was formed.

\section{Bromination of compound 5 with NBS and light}

A magnetically stirred mixture of compound $5(0.229 \mathrm{~g}, 1.0 \mathrm{mmol})$ and NBS (0.196 g, $1.1 \mathrm{mmol})$ in anhydrous $\mathrm{CCl}_{4}(15 \mathrm{~mL})$ was irradiated by a $100 \mathrm{~W}$ light bulb for $45 \mathrm{~min}$. The end of the reaction was monitored by tlc, because with longer irradiation times decomposition of the products is observed. The succinimide, which was formed, was removed by filtration. Concentration of the filtrate and purification by column chromatography on silica gel using a mixture of petroleum ether-EtOAc (4:1) as eluent to afford:

2-Bromo-4,5-dimethyl- $\boldsymbol{N}$-phenylacetylamido-1H-imidazole (10). 0.219 g, Yield 71\%, mp 193$195{ }^{\circ} \mathrm{C} .{ }^{1} \mathrm{H}$ NMR $\delta$ ppm: 2.01 (s, 3H, $\left.\mathrm{COCH}_{3}\right), 2.09$ (s, 3H, 5- $\left.\mathrm{CH}_{3}\right), 2.19$ (s, 3H, 4- $\left.\mathrm{CH}_{3}\right), 7.25-$ $7.28(\mathrm{~m}, 5 \mathrm{H}, \mathrm{Ph}) .{ }^{13} \mathrm{C}$ NMR $\delta$ ppm: $8.8\left(5-\mathrm{CH}_{3}\right), 13.2\left(4-\mathrm{CH}_{3}\right), 22.1\left(\mathrm{COCH}_{3}\right), 117.8(5), 121.6$ $\left(2^{\prime}, 6^{\prime}\right), 125.7$ (2), $126.6\left(4^{\prime}\right), 129.2\left(3^{\prime}, 5^{\prime}\right), 134.7$ (4), $139.2\left(1^{\prime}\right), 170.3(\mathrm{C}=\mathrm{O})$. EIMS: $m / z(\%)$ 307/309 (M+', 16), 266/268 (12), 228 (24), 186 (90), 173/175 (18), 145 (32), 118 (100). Anal. Calcd for $\mathrm{C}_{13} \mathrm{H}_{14} \mathrm{BrN}_{3} \mathrm{O}$ (308.17): C, 50.67; H, 4.58; N, 13.64. Found: C, 50.78 H, 5.54; N, 13.48 . When 2.0-5.0 eq. of NBS were used complicated mixtures of polybrominated imidazoles were formed. Finally, with 7.0 eq. of NBS and $1 \mathrm{~h}$ irradiation time only

2-Bromo-4,5-bisdibromomethyl- $\boldsymbol{N}$-phenylacetylamido- $\mathbf{H}$-imidazole (11) was isolated 0.375 g, 60\% yield, mp $150-152{ }^{\circ} \mathrm{C} .{ }^{1} \mathrm{H}$ NMR $\delta$ ppm: 2.17 (br s, 3H, $\left.\mathrm{COCH}_{3}\right), 6.58\left(\mathrm{~s}, 1 \mathrm{H}, 5-\mathrm{CHBr}_{2}\right.$ ), 7.03(s, 1H, 4-CHBr $)$ ), 7.33-7.50 (br m, 5H, Ph). ${ }^{13} \mathrm{C}$ NMR $\delta$ ppm: 18.9 (br, 5-CH), 22.3 $\left(\mathrm{COCH}_{3}\right), 28.6(4-\mathrm{CH}), 122.5$ (br, 2',6'), $123.6(5), 127.4$ (2), 128.4 (4'), 129.7 (3' ,5'), 138.6 (4), 140.0 (br, 1'), 168.8 (CO). EIMS: $m / z$ (\%) 619/621/623/625/627/629 $\left(\mathrm{M}^{+\cdot}, \quad 15\right)^{22}$, 540/542/544/546/548 (70), 92 (100). Anal. Calcd for $\mathrm{C}_{13} \mathrm{H}_{10} \mathrm{Br}_{5} \mathrm{~N}_{3} \mathrm{O}$ (623.76): C, 25.03; H, 1.62; N, 6.74. Found: C, 24.89 H, 1.54; N, 6.58.

\section{Bromination reaction of compound 5 with NBS and AIBN}

To a magnetically stirred mixture of $5(0.229 \mathrm{~g}, 1.0 \mathrm{mmol})$ and NBS $(0.214 \mathrm{~g}, 1.2 \mathrm{mmol})$ in anhydrous $\mathrm{CCl}_{4}(15 \mathrm{~mL})$ AIBN $(0.043 \mathrm{~g}, 0.2 \mathrm{mmol})$ was added and the mixture was stirred at room temperature for $24 \mathrm{~h}$. The succinimide, which was formed, was removed by filtration. Concentration of the filtrate and purification by column chromatography on silica gel, using a mixture of petroleum ether-EtOAc (4:1) as eluent, afforded compound 10, $0.20 \mathrm{~g}, 65 \%$ yield. 


\section{References and Notes}

1. Balaban, A. T.; Oniciu, D. C.; Katritzky, A. R. Chem. Rev. 2004, 104, 2777.

2. Pozharskii, A. F.; Soldatenkov, A. T.; Katritzky, A. R. Heterocycles in Life and Society; John Wiley and Sons: New York, 1997.

3. (a) Barnard, E. A.; Stein, W. D. Adv. Enzym. 1958, 20, 51. (b) Boiani, M.; Gomzalez, M. Mini-Rev. Med. Chem. 2005, 5, 409. (c) Jin, Z. Nat. Prod. Rep. 2005, 22, 196.

4. (a) Lipshutz, B. H. Chem. Rev. 1986, 86, 795. (b) Lagoja, I. M.; Pannecouque, C.; Van Aerschot, A.; Witvrouw, M.; Debyser, Z.; Balzarini, J.; Herdewijn, P.; De Clercq, E. J. Med. Chem. 2003, 46, 1546.

5. Nieto, I.; Cervantes-Lee, F.; Smith, J. M. Chem. Commun. 2005, 3811.

6. Herrmann, W. A. Angew. Chem. Int. Ed. 2002, 41, 1290.

7. César, V.; Bellemin-Laponnaz, S.; Gade, L. H. Chem. Soc. Rev. 2004, 33, 619.

8. (a) Herrmann, W. A.; Kocher, C. Angew. Chem. Int. Ed. 1997, 36, 2162. (b) Khramov, D. M.; Bielawski, C. W. Chem. Commun. 2005, 4958. (c) Majo, V. J.; Perumal, P. T. J. Org. Chem. 1998, 63, 7136. (d) Parenty, A. D. C.; Guthrie, K. M.; Song, Y.-F.; Smith, L. V.; Burkholder, E.; Cronin, L. Chem. Commun. 2006, 1194.

9. (a) Iddon, B. Heterocycles 1985, 23, 417. (b) Iddon, B.; Khan, N. J. Chem. Soc., Perkin Trans. 1, 1987, 1445. (c) Turner, R. M.; Lindell, S. D.; Ley, S. V. J. Org. Chem. 1991, 56, 5739.

10. Larock, R. C. Comprehensive Organic Transformations: A Guide to Functional Group Preparations; 1st Ed.; Wiley-VCH: New York, 1997.

11. Taylor, R. Electrophilic Aromatic Substitution; John Wiley and Sons: New York, 1990.

12. Bhujanga Rao, A. K. S.; Gundu Rao, C.; Singh, B. B. J. Org. Chem. 1992, 57, 3240.

13. Bahnous, M.; Mouats, C.; Fort, Y.; Gros, P.C. Tetrahedron Lett. 2006, 47, 1949.

14. Lee, S.-H.; Yoshida, K.; Matsushita, H.; Clapham, B.; Koch, G.; Zimmermann, J.; Janda, K. D. J. Org. Chem. 2004, 69, 8829.

15. Andrzejewska, M.; Pagano, M. A.; Meggio, F.; Brunati, A. M.; Kazimierczuk, Z. Biorg. Med. Chem. 2003, 11, 3997.

16. Lovely, C. J.; He, Y.; Fenton, H. M.; Dias, H. V. R. Heterocycles 2006, 70, 129.

17. Kikuchi, D.; Sakaguchi, S.; Ishii, Y. J. Org. Chem. 1998, 63, 6023.

18. Schantl, J. G.; Lagoja, I. M. Heterocycles 1997, 45, 691.

19. Schantl, J. G.; Lagoja, I. M. Heterocycles 1998, 48, 929.

20. Evans, D. A.; Bach, T. Angew. Chem., Int. Ed. 1993, 32, 1326.

21. Sun, C.; Lin, X.; Weinreb, S. M. J. Org. Chem. 2006, 71, 3159.

22 . The peak intensity refers to the higher peak of bromine containing ions. 